\title{
DAMPAK PENETAPAN HARGA OLEH TENGKULAK TERHADAP MINAT JUAL HASIL PERTANIAN
}

\author{
Maryani \\ Email: maryani140982@gmail.com \\ Universitas Islam Zainul Hasan Genggong \\ Sumiati \\ Universitas Islam Zainul Hasan Genggong
}

\begin{abstract}
In general, the determination of the price of coffee by a middleman is to look at it from several aspects, for the first time looking at the prevailing market price method in the market. Both the plus cost methods, based on the amount of costs incurred to produce the product, are added by a certain percentage of the costs. The third method of contribution margin is the difference between the selling price and the variable cost of a product. The four maximum profit methods, where the maximum profit will directly affect the product sales volume. Finally, the method of return on capital, which requires companies to use it as a basis for setting the selling price of products on the production capacity of the company. The results showed that the price-setting variable by the middleman $(X)$ had a positive and significant effect on the interest of coffee agricultural product sales (Y). This condition could be seen from the coefficient of the price-setting variable which was 0.424 and a significance of 0.000 (less than 0.05).
\end{abstract}

Keywords: Pricing, Agricultural Product Sales Interest 


\section{Pendahuluan}

Manusia sebagai makhuk sosial tidak bisa lepas dari bermuamalah antara satu dengan yang lainnya, Salah satu kerjasama kegiatan muamalah adalah kerjasama dalam hal jual beli. Dalam jual beli terdapat 3 komponen yang sangat penting yaitu penjual (pelaku usaha), pembeli (konsumen), serta barang yang akan diperjual belikan ${ }^{1}$. Dan dalam melakuakan transaksi jual beli harus sesuai dengan firman Allah SWT pada Q.S Al-Baqarah $2: 275$

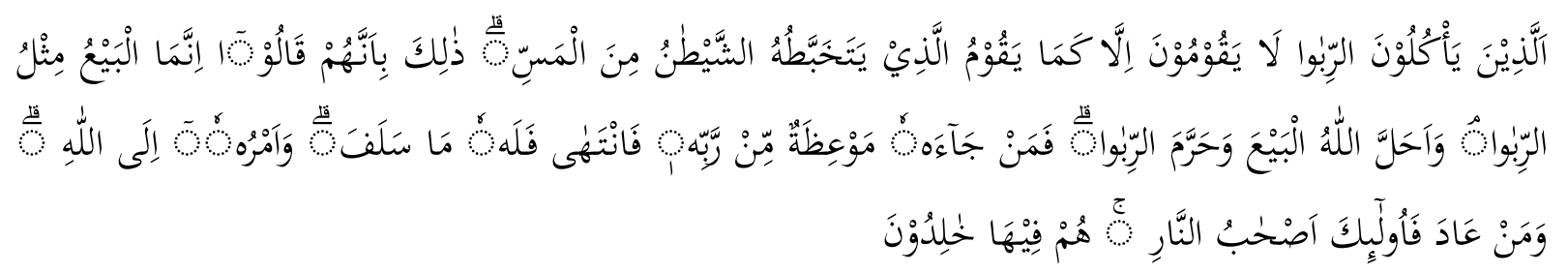

Artinya:

Orang-orang yang Makan (mengambil) riba tidak dapat berdiri melainkan seperti berdirinya orang yang kemasukan syaitan lantaran (tekanan) penyakit gila.Keadaan mereka yang demikian itu, adalah disebabkan mereka berkata (berpendapat), Sesungguhnya jual beli itu sama dengan riba, Padahal Allah telah menghalalkan jual beli dan mengharamkan riba. orang-orang yang telah sampai kepadanya larangan dari Tuhannya, lalu terus berhenti (dari mengambil riba), Maka baginya apa yang telah diambilnya dahul (sebelum datang larangan); dan urusannya (terserah) kepada Allah. orang yang kembali (mengambil riba), Maka orang itu adalah penghuni-penghuni neraka; mereka kekal di dalamnya (Q.S AlBaqarah 2:275).

Hukum Islam mengadakan aturan-aturan bagi keperluan dan membatasi keinginan hingga memungkinkan manusia memperoleh maksudnya tanpa memberi madharat kepada orang lain dan mengadakan hukum tukar-menukar keperluan antara masyarakat dalam satu jalan yang adil. Islam memberikan jalan kepada manusia untuk jual beli dengan dasar penentuan harga untuk menghindari kepicikan, kesukaran dan mendatangkan kemudahan ${ }^{2}$. Oleh karena itu Allah berfirman dalam Q.S an-Nisa/ 4: 29.

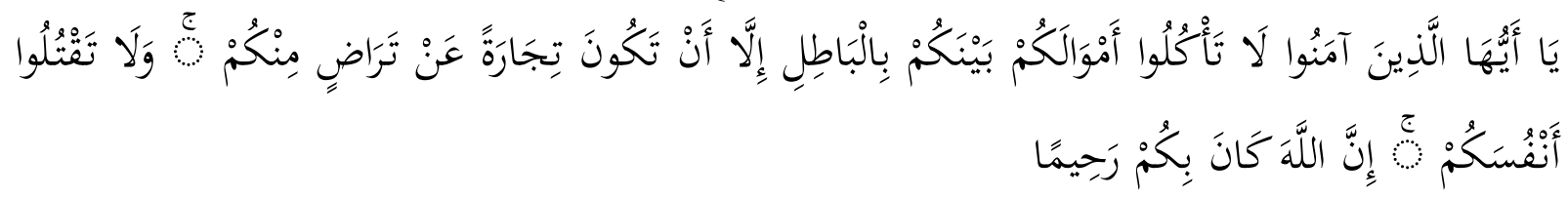

Artinya:

"Hai orang-orang yang beriman, janganlah kamu saling memakan harta sesamamu dengan jalan yang batil, kecuali dengan jalan perniagaan yan berlaku dengan suka samasuka diantara

\footnotetext{
${ }^{1}$ Artaty”Tinjauan Hukum Islam Tentang Praktek Tengkulak Dalam Jual Beli Karet Mentah”,(Skripsi, Universitas Islam Negeri Raden Intan Lampung,2017).

${ }^{2}$ Marfuah Siddik “Konsep Penetapan Harga Hasil perikanan dalam perspektif ekonomi islam” (Skripsi, Universitas Islam Negeri Alauddin Makassar,2016).
} 
kamu. Dan janganlah kamu membunuh dirimu;sesungguhnya Allah adalah Maha Penyayang kepadamu"(Q.S an-Nisa/ 4: 29).

Umumnya petani di Desa Ranuagung Kecamatan Tiris Kabupaten Probolinggo menjual hasil pertanian mereka melalui tengkulak. Prakteknya tengkulak yang membeli kopi tidak sesuai dengan yang diharapkan oleh petani, karna harga jual beli kopi seringkali berubah-rubah tanpa diketahui secara jelas oleh petani apa penyebab konkrit dari naik turunnya harga kopi tersebut. Posisi tawar menawar dalam harga bagi petani kopi hanya tawar menawar saja, tetapi harga tidak berubah dari harga awal dari tengkulak.

\section{Metode Penelitian}

Pendekatan yang di gunakan dalam penelitian ini adalah pendekatan yang bersifat kuantitatif karena mempunya variable bebas dan variable terikat dan bisa juga diangkakan, dianalisa berdasarkan analisis statistik.Dalam penelitian ini yang menjadi objek penelitian adalah analisis dampak penetapan harga oleh tengkulak terhadap minat penjualan hasil pertanian (haasil pertanian kopi di Dusun Komalang Desa Ranuagung Kecamatan Tiris) dengan variabel bebas (independent variable) dan variabel terikat (dependent variable) sebagai berikut: 1) Variabel bebas merupakan variabel yang mempengaruhi variabel terikat, yaitu Dampak Penetapan Harga Oleh Tengkulak (X); 2) Variabel terikat merupakan variabel yang dipengaruhi, yaitu Minat Penjualan Hasil Pertanian (Y).Dalam penelitian ini, peneliti menggunakan jenis instrumen angket atau kuesioner dengan pemberian skor sebagai berikut:

Tabel 3.2

Skala Likert

\begin{tabular}{|l|c|}
\hline \multicolumn{1}{|c|}{ Alternatif Jawaban } & Skor \\
\hline SS : Sangat Setuju & 5 \\
\hline S : Setuju & 4 \\
\hline KS : Kurang Setuju & 3 \\
\hline TS : Tidak Setuju & 2 \\
\hline STS : Sangat Tidak Setuju & 1 \\
\hline
\end{tabular}

Sumber : Rosady Ruslan $(2003: 187)^{3}$

Untuk mendapatkan hasil yang di inginkan dan memuaskan peneliti menyusun rancangan kisi-kisi instrumen penelitian, adapun kisi-kisi dari Instrumen penelitian ini adalah sebagai berikut :

${ }^{3}$ Wiratna,SPSS Untuk Peneitian (Yogyakarta: Pustaka Baru Press,2014), 38 
Tabel 3.3

Kisi-kisi Instrumen Penelitian

\begin{tabular}{|c|c|c|c|}
\hline Judul & Variabel & Indikator & No Item \\
\hline \multirow{7}{*}{$\begin{array}{l}\text { Analisis Dampak } \\
\text { Penetapan Harga } \\
\text { Oleh Tengkulak } \\
\text { Terhadap Minat } \\
\text { Penjualan Hasil } \\
\text { Pertanian } \\
\text { (Studi Kasus Hasil } \\
\text { Pertanian Kopi Di } \\
\text { Dusun Komalang } \\
\text { Desa Ranuagung } \\
\text { Kecamatan Tiris ) }\end{array}$} & \multirow[t]{2}{*}{$\begin{array}{l}\text { Penetapan Harga (X) } \\
\text { Variabel Independen }\end{array}$} & $\begin{array}{l}\text { Penetapan } \\
\text { Harga }\end{array}$ & $1,2,6,7$ \\
\hline & & $\begin{array}{l}\text { Perubahan } \\
\text { Harga }\end{array}$ & $3,4,5$ \\
\hline & \multirow[t]{5}{*}{$\begin{array}{l}\text { Minat Penjualan (Y) } \\
\text { Variabel Dependen }\end{array}$} & $\begin{array}{l}\text { Informasi } \\
\text { Harga }\end{array}$ & 1,2 \\
\hline & & Harga Jual & $3,4,5$ \\
\hline & & $\begin{array}{l}\text { Menjual Kopi } \\
\text { ke Pelanggan }\end{array}$ & 6 \\
\hline & & $\begin{array}{l}\text { Kebiasaan } \\
\text { Menjual Kopi } \\
\text { Setelah Panen }\end{array}$ & 7 \\
\hline & & $\begin{array}{l}\text { Menjual dalam } \\
\text { keadaan } \\
\text { mendesak }\end{array}$ & 8 \\
\hline
\end{tabular}

Teknik analisis data menggunakan: 1) Analisis Statistik Deskriptif, yaitu untuk mendeskripsikan atau menjelaskan tentang gambaran yang diteliti berdasarkan data dari variabel yang diperoleh, dalam hal ini analisis deskriptif adalah untuk menjelaskan tentang dampak penetapan harga oleh tengkulak terhadap minat penjualan hasil pertanian; 2) Analisis Regresi Linier Sederhanadi dasarkan pada hubungan fungsional atau kausal satu variable independen dengan satu variable dependen.

\section{Hasil Penelitian}

1. Gambaran Umum Lokasi Penelitian

Desa Ranuagung merupakan sebuah Desa yang terletak di Kecamatan Tiris Kabupaten Probolinggo yang mempunyai luas 974.990 Km2 dan ditinjau dari ketinggian diatas permukaan air laut, Kecamatan Tiris berada pada ketinggian 150-200 meter di atas permukaan air laut suhu udaranya relative dingin sebagaimana daerah dataran tinggi pada umumnya. ${ }^{4}$ Desa Ranuagung terdiri dari 7 Dusun yang terdiri dari Dusun Krajan, Dusun Komalang, Dusun Wates, Dusun Segaran Agung, Dusun Tancak/Longge'en, Dusun Tancak dan Dusun Betok, dan terdiri dari 7 RW dan 18 RT dengan jumlah

${ }^{4}$ Yundaliana, Analisis Fertilitas Di Desa Ranuagung Kecamatan Tiris Kabupaten Probolinggo, Artikel Ilmiah mahasiswa (Online), Tahun 2015. http:// www.Yundaliana.pdf, diakses pada 12 juli 2019. 
penduduk sebanyak 8.566 dengan jumlah Laki-laki sebanyak 4.059 jiwa dan jumlah perempuan sebanyak 4.507 jiwa dengan jumlah KK sebanyak $2.190 .^{5}$

Seperti yang telah di jelaskan diatas bahwasanya Desa Ranuagung Kecamatan Tiris merupakan wilayah pegunungan dengan letak geografis yang berada dipegunungan serta suhu udara yang sejuk membuat daerah Desa Ranuagung Kecamatan Tiris berpotensi menghasilkan sumber daya alam yang melimpah khususnya dalam bidang perkebunan dan pertanian seperti: alpukat, kelapa, duren, kayu sengon, padi, jagung, manggis, pisang, kopi, dan lain sebagainya, akan tetapi tanaman yang paling banyak ditanam oleh masyarakat Desa Ranuagung adalah tanaman kopi, manggis, pisang dan kelapa. walaupun demikian juga tidak sedikit yang bekerja sebagai pegawai negeri sipil (PNS) dan pedagang.

Dusun Komalang terletak bagian timur, Dusun Wates dibagian selatan, Dusun Krajan dibagian utara, sedangkan untuk Dusun Segaran Agung, Dusun Tancak/Longge'en, Dusun Tancak dan Dusun Betok terletak di bagian timur. Jumlah penduduk di Dusun Komalang sebanyak 1833, dengan jumlah KK sebanyak 460 jiwa yang terdiri dari laki-laki sebanyak 885 dan perempuan 946.

2. Deskripsi Data

Dalam penelitian ini Jumlah responden yang di ambil adalah sebanyak 66 masyarakat dan berikut ini akan di sajikan deskripsi data responden berdasarkan karakteristik. Adapun jenis responden berdasarkan krakteristik sebagai berikut:

a. Karakteristik Menurut Pekerjaan

Berdasarkan kuesioner yang telah disebar kepada responden, maka dapat di ketahui data sesuai pekerjaan yaitu sebagai berikut:

Tabel 4.1

Distribusi Pekerjaan Responden

\begin{tabular}{|l|c|c|}
\hline \multicolumn{1}{|c|}{ Pekerjaan } & Responden & Presentase \% \\
\hline Lain-lain & 30 & $45,5 \%$ \\
\hline Wiraswasta & 16 & $24,2 \%$ \\
\hline Petani & 16 & $24,2 \%$ \\
\hline Karyawan & 4 & $6 \%$ \\
\hline Jumlah & 66 & $100 \%$ \\
\hline
\end{tabular}

Sumber: Data diolah

Dari Tabel 4.1 dapat dilihat bahwasanya pekerjaan responden yang paling mendominan adalah Lain-lain yaitu dengan jumlah sebanyak 30 orang dengan presentase $19,8 \%$, sedangkan untuk yang berprofesi sebagai wiraswasta dan petani

${ }^{5}$ Saifullah, Rekapitulasi Jumlah Jiwa dan Kepala Keluarga Desa Ranuagung Kecamatan Tiris Tahun 2019. 
memiliki jumlah yang sama yaitu sebanyak 16 orang dengan presentase $10,56 \%$, sedangkan untuk yang terakhir adalah responden yang berprofesi sebagai karyawan yaitu dengan jumlah sebanyak 4 orang dengan presentase 2,64 \%.

b. Karakteristik Menurut Jumlah Pendapatan

Berdasarkan kuesioner yang telah disebar kepada responden, maka dapat di ketahui data sesuai penghasilan yaitu sebagai berikut:

Tabel 4.2

Distribusi Penghasilan Responden

\begin{tabular}{|l|c|c|}
\hline \multicolumn{1}{|c|}{ Pekerjaan } & Responden & Presentase \% \\
\hline$<1.000 .000$ & 42 & $63,6 \%$ \\
\hline $1.000 .000-2.000 .000$ & 22 & $33,3 \%$ \\
\hline$>3.000 .000$ & 2 & $3 \%$ \\
\hline Jumlah & 66 & $100 \%$ \\
\hline
\end{tabular}

\section{Sumber: Data diolah}

Dari tabel 4, diatas dapat diketahui bahwa penghailan responden yang paling mendominan $<1.000 .000$ sebanyak 42 responden dengan persentase 27,72\%. Sedangkan jumalh responden yang berpenghasilan $1.000 .000-2.000 .000$ adalah 22 responden dengan persentase $14,52 \%$. Sedangkan untuk responden yang berpenghasillan $>$ 3.000.000 adalah sebanyak dengan presentase $1,32 \%$.

3. Analisis Data

a. Statistik Deskriptif

Analisis deskriptif untuk mendeskripsikan atau menjelaskan tentang gambaran yang diteliti berdasarkan data dari variabel yang diperoleh, dalam hal ini analisis deskriptif adalah untuk menjelaskan tentang dampak penetapan harga oleh tengkulak terhadap minat penjualan hasil pertanian. 
1) Rekapitulasi Data uji Statitistik Deskriptif untuk variabel Penetapan Harga (X)

Tabel. 4.3

Penetapan Harga (Variabel X)

\begin{tabular}{|c|c|c|c|c|c|c|c|c|c|c|}
\hline \multirow{3}{*}{$\begin{array}{c}\text { Variabel } \\
\text { X_1 }\end{array}$} & \multicolumn{10}{|c|}{ Jumlah Responden dan Persentase \% } \\
\hline & \multicolumn{2}{|r|}{ SS } & \multicolumn{2}{|r|}{$\mathbf{S}$} & \multicolumn{2}{|c|}{ KS } & \multicolumn{2}{|c|}{ TS } & \multicolumn{2}{|c|}{ STS } \\
\hline & 0 & $0.0 \%$ & 3 & $4.5 \%$ & 35 & $53.0 \%$ & 26 & $39.4 \%$ & 2 & $3.0 \%$ \\
\hline X_2 & 2 & $3.0 \%$ & 12 & $18.2 \%$ & 37 & $56.1 \%$ & 15 & $22.7 \%$ & 0 & $0.0 \%$ \\
\hline X_3 & 2 & $3.0 \%$ & 8 & $12.1 \%$ & 3 & $4.5 \%$ & 48 & $72.7 \%$ & 5 & $7.6 \%$ \\
\hline X_4 & 10 & $15.2 \%$ & 15 & $22.7 \%$ & 8 & $12.1 \%$ & 32 & $48.5 \%$ & 1 & $1.5 \%$ \\
\hline X_5 & 0 & $0.0 \%$ & 1 & $1.5 \%$ & 3 & $4.5 \%$ & 44 & $66.7 \%$ & 18 & $27.3 \%$ \\
\hline X_6 & 2 & $3.0 \%$ & 10 & $15.2 \%$ & 38 & $57.6 \%$ & 11 & $16.7 \%$ & 5 & $7.8 \%$ \\
\hline X_7 & 7 & $10.6 \%$ & 5 & $7.6 \%$ & 37 & $56.1 \%$ & 17 & 25.8 & 0 & $0.0 \%$ \\
\hline
\end{tabular}

Sumber: Data diolah dengan program SPSS 16,0

Adapun pemaparan mengenai hasil dari uji statistik deskriptif utuk variabel penetapan haraga $(\mathrm{X})$ adalah sebagai berikut:

Tabel. 4.3.1

Hasil uji Statitistik Deskriptif untuk variabel Penetapan Harga (X_1)

\begin{tabular}{|c|c|c|c|c|c|}
\hline \multicolumn{6}{|c|}{ X_1 } \\
\hline & & Frequency & Percent & Valid Percent & $\begin{array}{c}\text { Cumulative } \\
\text { Percent }\end{array}$ \\
\hline \multirow[t]{5}{*}{ Valid } & TS & 3 & 4.5 & 4.5 & 4.5 \\
\hline & KS & 35 & 53.0 & 53.0 & 57.6 \\
\hline & $S$ & 26 & 39.4 & 39.4 & 97.0 \\
\hline & SS & 2 & 3.0 & 3.0 & 100.0 \\
\hline & Total & 66 & 100.0 & 100.0 & \\
\hline
\end{tabular}

Sumber : Data diolah dengan progam SPSS versi 16,0

Variabel X_1 dalam hal ini responden yang mengetahui pernyataan tentang harga yang di tetapkan oleh tengkulak sesuai dengan harga yang beredar di pasaran, maka 
jumlah responden yang menjawab sangat setuju sebanyak 2 responden atau 3,0\%, setuju sebanyak 26 responden atau 39,4\%, kurang setuju sebanyak 35 responden atau 53,0\%, tidak setuju sebanyak 3 responden atau 4,5\% dan sangat tidak setuju sebanyak 0 responden atau .0\%. Maka berdasarkan data diatas dapat disimpulkan bahwa mayoritas responden kurang setuju dengan harga yang di tetapkan oleh tengkulak sesuai dengan harga yang beredar di pasaran.

Tabel. 4.3.2

Hasil uji Statitistik Deskriptif untuk variabel Penetapan Harga (X_2)

$\mathrm{X} \_2$

\begin{tabular}{|ll|r|r|r|r|}
\hline & Frequency & Percent & Valid Percent & \multicolumn{2}{c|}{$\begin{array}{c}\text { Pumulative } \\
\text { Percent }\end{array}$} \\
\hline Valid & STS & 2 & 3.0 & 3.0 & 3.0 \\
& 12 & 18.2 & 18.2 & 21.2 \\
& TS & 37 & 56.1 & 56.1 & 77.3 \\
KS & 15 & 22.7 & 22.7 & 100.0 \\
S & 66 & 100.0 & 100.0 & \\
Total & & & \\
\hline
\end{tabular}

Sumber : Data diolah dengan progam SPSS versi 16,0

Variabel X_2 dalam hal ini responden yang mengetahui pernyataan tentang harga yang di tetapkan tengkulak berbeda jauh dengan harga yang beredar di pasaran, maka jumlah responden yang menjawab sangat setuju sebanyak 0 responden atau $0,0 \%$, setuju sebanyak 15 responden atau $22,7 \%$, kurang setuju sebanyak 37 responden atau $56,1 \%$, tidak setuju sebanyak 12 responden atau 18,2\% dan sangat tidak setuju sebanyak 2 responden atau 3.0\%. Maka berdasarkan data diatas dapat disimpulkan bahwa mayoritas responden kurang setuju dengan harga yang di tetapkan tengkulak berbeda jauh dengan harga yang beredar di pasaran.

Tabel. 4.3.3

Hasil uji Statitistik Deskriptif untuk variabel Penetapan Harga (X_3)

X_3

\begin{tabular}{|ll|r|r|r|r|}
\hline & Frequency & Percent & Valid Percent & $\begin{array}{c}\text { Cumulative } \\
\text { Percent }\end{array}$ \\
\hline Valid STS & 2 & 3.0 & 3.0 & 3.0 \\
& TS & 8 & 12.1 & 12.1 & 15.2 \\
& 3 & 4.5 & 4.5 & 19.7 \\
KS & 38 & 72.7 & 72.7 & 92.4 \\
S & 5 & 7.6 & 7.6 & 100.0 \\
SS & 66 & 100.0 & 100.0 & \\
\hline
\end{tabular}

Sumber : Data diolah dengan progam SPSS versi 16,0 
Variabel X_3 dalam hal ini responden yang mengetahui pernyataan tentang harga kopi sering berubah-ubah tanpa diketahui penyebabnya, maka jumlah responden yang menjawab sangat setuju sebanyak 5 responden atau 7,6\%, setuju sebanyak 48 responden atau $72,7 \%$, kurang setuju sebanyak 3 responden atau 4,5\%, tidak setuju sebanyak 8 responden atau $12,1 \%$ dan sangat tidak setuju sebanyak 2 responden atau 3,0\%. Maka berdasarkan data diatas dapat disimpulkan bahwa mayoritas responden setuju dengan harga kopi sering berubah-ubah tanpa di ketahui penyebabnya.

Tabel. 4.3.4

Hasil uji Statitistik Deskriptif untuk variabel Penetapan Harga (X_4)

X_4

\begin{tabular}{|ll|r|r|r|r|}
\hline & Frequency & Percent & Valid Percent & $\begin{array}{c}\text { Cumulative } \\
\text { Percent }\end{array}$ \\
\hline Valid & STS & 10 & 15.2 & 15.2 & 15.2 \\
& TS & 15 & 22.7 & 22.7 & 37.9 \\
& KS & 8 & 12.1 & 12.1 & 50.0 \\
S & 32 & 48.5 & 48.5 & 98.5 \\
S & 1 & 1.5 & 1.5 & 100.0 \\
& 66 & 100.0 & 100.0 & \\
\hline
\end{tabular}

Sumber : Data diolah dengan progam SPSS versi 16,0

Variabel X_4 dalam hal ini responden yang mengetahui pernyataan tentang harga kopi seringkali naik sehingga memicu para petani untuk menjual hasil panen sebelum waktunya, maka jumlah responden yang menjawab sangat setuju sebanyak 1 responden atau $1,5 \%$, setuju sebanyak 32 responden atau 48,5\%, kurang setuju sebanyak 8 responden atau $12,1 \%$, tidak setuju sebanyak 15 responden atau $22,7 \%$ dan sangat tidak setuju sebanyak 10 responden atau 15,2\%. Maka berdasarkan data diatas dapat disimpulkan bahwa mayoritas responden setuju dengan harga kopi seringkali naik sehingga memicu para petani untuk menjual hasil panen sebelum waktunya.

Tabel. 4.3.5

Hasil uji Statitistik Deskriptif untuk variabel Penetapan Harga (X_5)

\begin{tabular}{|c|c|c|c|c|c|}
\hline \multicolumn{6}{|c|}{ X_5 } \\
\hline & & Frequency & Percent & Valid Percent & $\begin{array}{c}\text { Cumulative } \\
\text { Percent }\end{array}$ \\
\hline \multirow[t]{4}{*}{ Valid } & TS & 1 & 1.5 & 1.5 & 1.5 \\
\hline & KS & 3 & 4.5 & 4.5 & 6.1 \\
\hline & $\mathrm{s}$ & 44 & 66.7 & 66.7 & 72.7 \\
\hline & SS & 18 & 27.3 & 27.3 & 100.0 \\
\hline
\end{tabular}




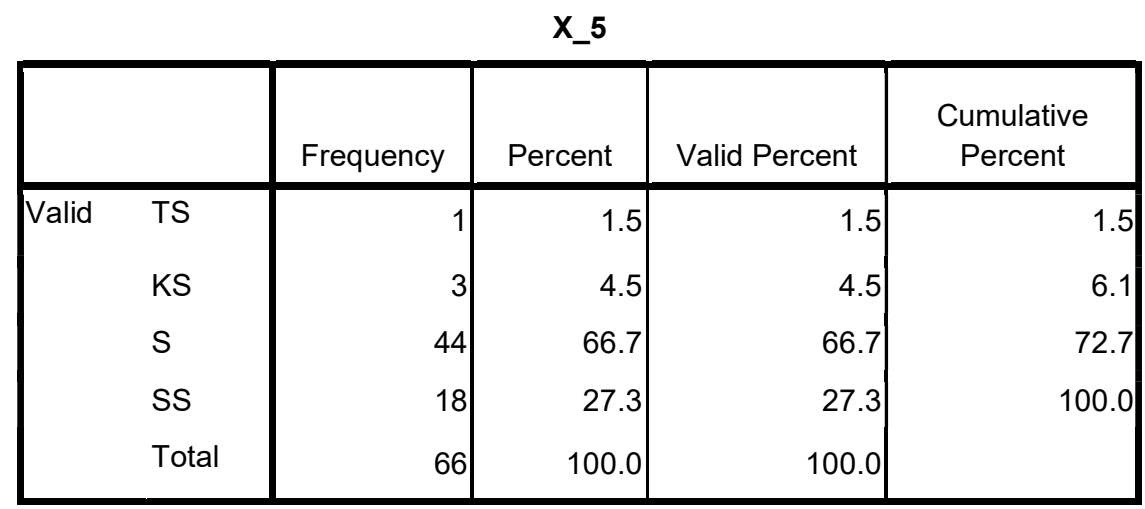

\section{Sumber : Data diolah dengan progam SPSS versi 16,0}

Variabel X_5 dalam hal ini responden yang mengetahui pernyataan tentang Harga kopi seringkali bersaing dengan tengkulak lainnya sehingga memicu para petani untuk memilih tengkulak yang bisa memberikan harga yang lebih mahal, maka jumlah responden yang menjawab sangat setuju sebanyak 18 responden atau $27,3 \%$, setuju sebanyak 44 responden atau $66,7 \%$, kurang setuju sebanyak 3 responden atau 4,5\%, tidak setuju sebanyak 1 responden atau 1,5\% dan sangat tidak setuju sebanyak 0 responden atau $0,0 \%$. Maka berdasarkan data diatas dapat disimpulkan bahwa mayoritas responden setuju dengan Harga kopi seringkali bersaing dengan tengkulak lainnya sehingga memicu para petani untuk memilih tengkulak yang bisa memberikan harga yang lebih mahal.

Tabel. 4.3.6

\section{Hasil uji Statitistik Deskriptif untuk variabel Penetapan Harga (X_6)}

\begin{tabular}{|l|r|r|r|r|}
\hline & Frequency & Percent & Valid Percent & $\begin{array}{c}\text { Cumulative } \\
\text { Percent }\end{array}$ \\
\hline Valid STS & 2 & 3.0 & 3.0 & 3.0 \\
& 10 & 15.2 & 15.2 & 18.2 \\
TS & 38 & 57.6 & 57.6 & 75.8 \\
KS & 11 & 16.7 & 16.7 & 92.4 \\
S & 5 & 7.6 & 7.6 & 100.0 \\
SS & 66 & 100.0 & 100.0 & \\
Total & & & \\
\hline
\end{tabular}

Sumber : Data diolah dengan progam SPSS versi 16,0

Variabel X_6 dalam hal ini responden yang mengetahui pernyataan tentang Harga beli dari tengkulak sesuai dengan yang di harapkan oleh para petani kopi, maka jumlah responden yang menjawab sangat setuju sebanyak 5 responden atau 7,6\%, setuju sebanyak 11 responden atau 16,7\%, kurang setuju sebanyak 38 responden atau 57,6\%, tidak setuju sebanyak 10 responden atau $15,2 \%$ dan sangat tidak setuju sebanyak 2 responden atau 3,0\%. Maka berdasarkan data diatas dapat disimpulkan bahwa mayoritas 
responden kurang setuju dengan Harga beli dari tengkulak sesuai dengan yang di harapkan oleh para petani kopi.

Tabel. 4.3.7

Hasil uji Statitistik Deskriptif untuk variabel Penetapan Harga (X_7)

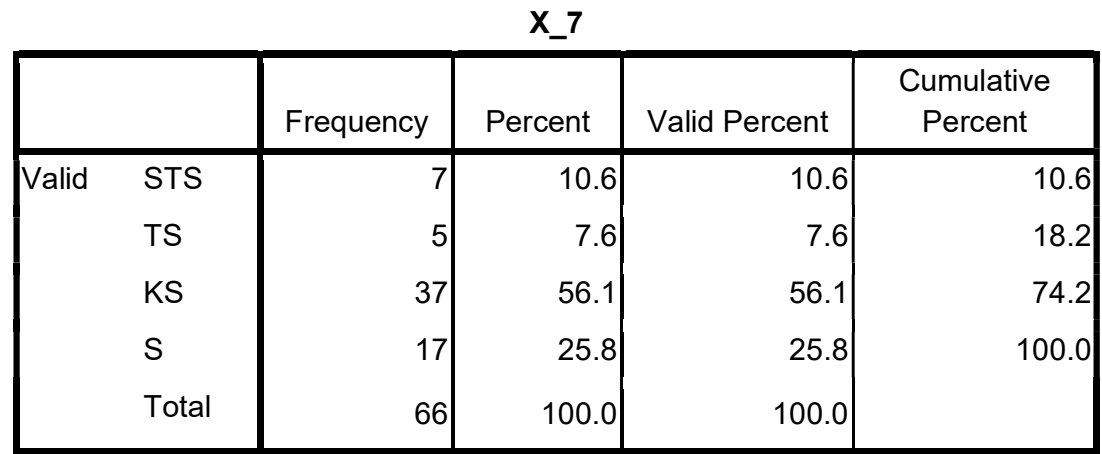

Sumber : Data diolah dengan progam SPSS versi 16,0

Variabel X_7 dalam hal ini responden yang mengetahui pernyataan tentang Harga yang di terapkan oleh tengkulak termasuk harga yang stabil dalam kurun waktu tertentu, maka jumlah responden yang menjawab sangat setuju sebanyak 0 responden atau $0,0 \%$, setuju sebanyak 17 responden atau $25,8 \%$, kurang setuju sebanyak 37 responden atau $56,1 \%$, tidak setuju sebanyak 5 responden atau 7,6\% dan sangat tidak setuju sebanyak 7 responden atau 10,6\%. Maka berdasarkan data diatas dapat disimpulkan bahwa mayoritas responden kurang setuju dengan Harga yang di terapkan oleh tengkulak termasuk harga yang stabil dalam kurun waktu tertentu.

a. Rekapitulasi data uji Statitistik Deskriptif untuk variabel Minat Jual (Y).

Tabel. 4.4

Minal Jual (Variabel Y)

\begin{tabular}{|c|c|c|c|c|c|c|c|c|c|c|}
\hline \multirow{2}{*}{ Variabel } & \multicolumn{6}{|c|}{ Jumlah Responden dan Persentase \% } \\
\cline { 2 - 11 } & \multicolumn{2}{|c|}{ SS } & \multicolumn{2}{|c|}{ S } & \multicolumn{2}{c|}{ KS } & \multicolumn{2}{c|}{ TS } & \multicolumn{2}{c|}{ STS } \\
\hline Y_1 & 0 & $0.0 \%$ & 0 & $0.0 \%$ & 3 & $4.5 \%$ & 18 & $27.3 \%$ & 45 & $68.2 \%$ \\
\hline Y_2 & 0 & $0.0 \%$ & 3 & $4.5 \%$ & 1 & $1.5 \%$ & 24 & $36.4 \%$ & 38 & $57.6 \%$ \\
\hline Y_3 & 1 & $1.5 \%$ & 0 & $0.0 \%$ & 1 & $1.5 \%$ & 39 & $59.1 \%$ & 25 & $37.9 \%$ \\
\hline Y_4 & 1 & $1.5 \%$ & 4 & $6.1 \%$ & 42 & $63.6 \%$ & 16 & $24.2 \%$ & 3 & $4.5 \%$ \\
\hline
\end{tabular}




\begin{tabular}{|l|l|l|l|l|l|l|l|l|l|l|}
\hline Y_5 & 0 & $0.0 \%$ & 6 & $9.1 \%$ & 47 & $71.2 \%$ & 13 & $19.7 \%$ & 0 & $0.0 \%$ \\
\hline Y_6 & 0 & $0.0 \%$ & 15 & $22.7 \%$ & 14 & $21.2 \%$ & 34 & $51.5 \%$ & 3 & $4.5 \%$ \\
\hline Y_7 & 1 & $1.5 \%$ & 16 & $24.2 \%$ & 17 & $25.8 \%$ & 24 & $36.4 \%$ & 8 & $12.1 \%$ \\
\hline Y_8 & 2 & $3.0 \%$ & 14 & $21.2 \%$ & 36 & $54.5 \%$ & 10 & $15.2 \%$ & 4 & $6.1 \%$ \\
\hline
\end{tabular}

Sumber: Data diolah dengan program SPSS 16.0

Adapun pemaparan mengenai hasil dari uji statistik deskriptif utuk variabel minat julan (Y) adalah sebagai berikut:

Tabel. 4.4.1

Hasil uji Statitistik Deskriptif untuk variabel Minat Jual (Y_1)

\begin{tabular}{|ll|r|r|r|r|}
\hline & & Y_1 & \\
\hline Valid & KS & 3 & 4.5 & 4.5 & 4.5 \\
& S & 18 & 27.3 & 27.3 & 31.8 \\
& SS & 45 & 68.2 & 68.2 & 100.0 \\
& Total & 66 & 100.0 & 100.0 & \\
\hline
\end{tabular}

Sumber: Data diolah dengan program SPSS 16.0

Variabel Y_1 dalam hal ini pernyataan bahwa responden mencari informasi sebelum menjual kopi kepada tengkulak, maka jumlah responden yang menjawab sangat setuju sebanyak 45 responden atau $68,3 \%$, setuju sebanyak 18 responden atau $27,3 \%$, kurang setuju sebanyak 3 responden atau 4,5\%, tidak setuju sebanyak 0 responden atau $0,0 \%$ dan sangat tidak setuju sebanyak 0 responden atau $0,0 \%$. Maka berdasarkan data diatas dapat disimpulkan bahwa mayoritas responden sangat setuju dengan mencari informasi sebelum menjual kopi kepada tengkulak.

Tabel. 4.4.2

Hasil uji Statitistik Deskriptif untuk variabel Minat Jual (Y_2)

Y 2

\begin{tabular}{|c|c|c|c|c|c|}
\hline & & Frequency & Percent & Valid Percent & $\begin{array}{c}\text { Cumulative } \\
\text { Percent }\end{array}$ \\
\hline \multirow[t]{3}{*}{ Valid } & TS & 3 & 4.5 & 4.5 & \\
\hline & KS & 1 & 1.5 & 1.5 & \\
\hline & $\mathrm{s}$ & 24 & 36.4 & 36.4 & \\
\hline
\end{tabular}




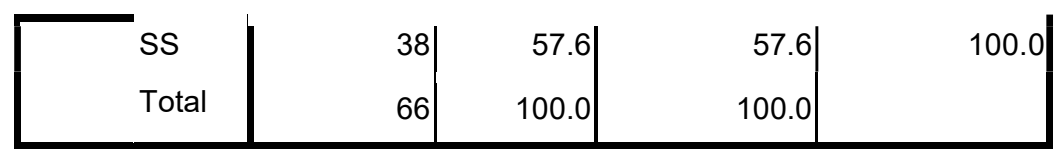

Sumber: Data diolah dengan program SPSS 16.0

Variabel Y_2 dalam hal ini pernyataan bahwa responden mencari informasi mengenai tengkulak yang membeli kopi dengan harga yang lebih tinggi, maka jumlah responden yang menjawab sangat setuju sebanyak 38 responden atau 57,6\%, setuju sebanyak 24 responden atau 36,4\%, kurang setuju sebanyak 1 responden atau 1,5\%, tidak setuju sebanyak 3 responden atau 4,5\% dan sangat tidak setuju sebanyak 0 responden atau $0,0 \%$. Maka berdasarkan data diatas dapat disimpulkan bahwa mayoritas responden sangat setuju dengan mencari informasi mengenai tengkulak yang membeli kopi dengan harga yang lebih tinggi.

Tabel. 4.4.3

Hasil uji Statitistik Deskriptif untuk variabel Minat Jual (Y_3)

Y_3

\begin{tabular}{|ll|r|r|r|r|}
\hline & Frequency & Percent & Valid Percent & \multicolumn{2}{|c|}{ Pumulative } \\
\hline Valid & STS & 1 & 1.5 & 1.5 & 1.5 \\
& KS & 1 & 1.5 & 1.5 & 3.0 \\
& S & 39 & 59.1 & 59.1 & 62.1 \\
SS & 25 & 37.9 & 37.9 & 100.0 \\
& Total & 66 & 100.0 & 100.0 & \\
\hline
\end{tabular}

Sumber: Data diolah dengan program SPSS 16.0

Variabel Y_3 dalam hal ini pernyataan bahwa responden menjual kopi setelah mengetahui harga yang di tentukan oleh tengkulak, maka jumlah responden yang menjawab sangat setuju sebanyak 25 responden atau 37,9\%, setuju sebanyak 39 responden atau 59,1\%, kurang setuju sebanyak 1 responden atau $1,5 \%$, tidak setuju sebanyak 0 responden atau $0,0 \%$ dan sangat tidak setuju sebanyak 1 responden atau 1,5\%. Maka berdasarkan data diatas dapat disimpulkan bahwa mayoritas responden setuju dengan pernyataan menjual kopi setelah mengetahui harga yang di tentukan oleh tengkulak.

Tabel. 4.4.4

Hasil uji Statitistik Deskriptif untuk variabel Minat Jual (Y_4)

\begin{tabular}{|c|c|c|c|c|c|}
\hline \multicolumn{6}{|c|}{ Y_4 } \\
\hline & & Frequency & Percent & Valid Percent & $\begin{array}{c}\text { Cumulative } \\
\text { Percent }\end{array}$ \\
\hline Valid & STS & 1 & 1.5 & 1.5 & 1.5 \\
\hline & TS & 4 & 6.1 & 6.1 & 7.6 \\
\hline & KS & 42 & 63.6 & 63.6 & 71. \\
\hline
\end{tabular}




\begin{tabular}{l|r|r|r|r|}
\hline S & 16 & 24.2 & 24.2 & 95.5 \\
SS & 3 & 4.5 & 4.5 & 100.0 \\
Total & 66 & 100.0 & 100.0 & \\
\hline
\end{tabular}

Sumber: Data diolah dengan program SPSS 16.0

Variabel Y_4 dalam hal ini pernyataan bahwa responden tetap menjual kopi walaupun harga kopi terbilang murah, maka jumlah responden yang menjawab sangat setuju sebanyak 3 responden atau 4,5\%, setuju sebanyak 16 responden atau 24,2\%, kurang setuju sebanyak 42 responden atau $63,6 \%$, tidak setuju sebanyak 4 responden atau $6,1 \%$ dan sangat tidak setuju sebanyak 1 responden atau 1,5\%. Maka berdasarkan data diatas dapat disimpulkan bahwa mayoritas responden kurang setuju dengan pernyataan tetap menjual kopi walaupun harga kopi terbilang murah.

Tabel. 4.4.5

Hasil uji Statitistik Deskriptif untuk variabel Minat Jual (Y_5)

Y_5

\begin{tabular}{|ll|r|r|r|r|}
\hline & Frequency & Percent & Valid Percent & \multicolumn{2}{c|}{ Pumulative } \\
\hline Valid & TS & 6 & 9.1 & 9.1 & 9.1 \\
& KS & 47 & 71.2 & 71.2 & 80.3 \\
& S & 13 & 19.7 & 19.7 & 100.0 \\
& Total & 66 & 100.0 & 100.0 & \\
\hline
\end{tabular}

Sumber: Data diolah dengan program SPSS 16.0

Variabel Y_5 dalam hal ini pernyataan bahwa responden hanya menjual kopi di saat harga sesuai dengan yang saya inginkan/ mahal, maka jumlah responden yang menjawab sangat setuju sebanyak 0 responden atau $0,0 \%$, setuju sebanyak 13 responden atau 19,7\%, kurang setuju sebanyak 47 responden atau 71,2\%, tidak setuju sebanyak 6 responden atau $9,1 \%$ dan sangat tidak setuju sebanyak 0 responden atau $0,0 \%$. Maka berdasarkan data diatas dapat disimpulkan bahwa mayoritas responden kurang setuju dengan pernyataan hanya menjual kopi di saat harga sesuai dengan yang saya inginkan/ mahal.

Tabel. 4.4.1

Hasil uji Statitistik Deskriptif untuk variabel Minat Jual (Y_6)

Y_6

\begin{tabular}{|c|c|c|c|c|c|}
\hline & & Frequency & Percent & Valid Percent & $\begin{array}{c}\text { Cumulative } \\
\text { Percent }\end{array}$ \\
\hline \multirow[t]{2}{*}{ Valid } & TS & 15 & 22.7 & 22.7 & 22 \\
\hline & KS & 14 & 21.2 & 21.2 & \\
\hline
\end{tabular}




\begin{tabular}{|l|r|r|r|r|}
\hline S & 34 & 51.5 & 51.5 & 95.5 \\
SS & 3 & 4.5 & 4.5 & 100.0 \\
Total & 66 & 100.0 & 100.0 & \\
\hline
\end{tabular}

Sumber: Data diolah dengan program SPSS 16.0

Variabel Y_6 dalam hal ini pernyataan bahwa responden hanya menjual kopi kepada tengkulak langganan saya, maka jumlah responden yang menjawab sangat setuju sebanyak 3 responden atau 4,5\%, setuju sebanyak 34 responden atau 51,5\%, kurang setuju sebanyak 14 responden atau $21,2 \%$, tidak setuju sebanyak 15 responden atau $22,7 \%$ dan sangat tidak setuju sebanyak 0 responden atau $0,0 \%$. Maka berdasarkan data diatas dapat disimpulkan bahwa mayoritas responden setuju dengan pernyataan hanya menjual kopi kepada tengkulak langganan saya.

Tabel. 4.4.7

Hasil uji Statitistik Deskriptif untuk variabel Minat Jual (Y_7)

Y_7

\begin{tabular}{|ll|r|r|r|r|}
\hline & Frequency & Percent & Valid Percent & \multicolumn{2}{|c|}{ Percent } \\
\hline Valid & STS & 1 & 1.5 & 1.5 & 1.5 \\
& TS & 16 & 24.2 & 24.2 & 25.8 \\
& 17 & 25.8 & 25.8 & 51.5 \\
KS & 24 & 36.4 & 36.4 & 87.9 \\
S & 8 & 12.1 & 12.1 & 100.0 \\
SS & 66 & 100.0 & 100.0 & \\
Total & &
\end{tabular}

Sumber: Data diolah dengan program SPSS 16.0

Variabel Y_7 dalam hal ini pernyataan bahwa responden menjual kopi karena sudah menjadi kebiasan setelah penen kopi langsung menjual kepada tengkulak maupun harganya murah atau mahal, maka jumlah responden yang menjawab sangat setuju sebanyak 8 responden atau $12,1 \%$, setuju sebanyak 24 responden atau 36,4\%, kurang setuju sebanyak 17 responden atau $25,8 \%$, tidak setuju sebanyak 16 responden atau $24,2 \%$ dan sangat tidak setuju sebanyak 1 responden atau 1,5\%. Maka berdasarkan data diatas dapat disimpulkan bahwa mayoritas responden setuju dengan pernyataan menjual kopi karena sudah menjadi kebiasan setelah penen kopi langsung menjual kepada tengkulak maupun harganya murah atau mahal. 
Tabel. 4.4.8

Hasil uji Statitistik Deskriptif untuk variabel Minat Jual (Y_8)

\begin{tabular}{|ll|r|r|r|r|}
\hline & Y_8 \\
\hline Valid & STS & 2 & 3.0 & 3.0 & 3.0 \\
& TS & 14 & 21.2 & 21.2 & 24.2 \\
& KS & 36 & 54.5 & 54.5 & 78.8 \\
& S & 10 & 15.2 & 15.2 & 93.9 \\
SS & 4 & 6.1 & 6.1 & 100.0 \\
& Total & 66 & 100.0 & 100.0 & \\
\hline
\end{tabular}

Sumber: Data diolah dengan program SPSS 16.0

Variabel Y_8 dalam hal ini pernyataan bahwa responden menjual kopi disaat membutuhkan uang saja/ keperluan mendesak, maka jumlah responden yang menjawab sangat setuju sebanyak 4 responden atau 6,1\%, setuju sebanyak 10 responden atau 15,2\%, kurang setuju sebanyak 36 responden atau 54,5\%, tidak setuju sebanyak 14 responden atau 21,2\% dan sangat tidak setuju sebanyak 2 responden atau 3,0\%. Maka berdasarkan data diatas dapat disimpulkan bahwa mayoritas responden kurang setuju dengan pernyataan menjual kopi disaat membutuhkan uang saja/ keperluan mendesak.

b. Hasil Analisisis Uji Validitas

Uji Validitas adalah Uji kevalidan atau ketepatan maupun ketelitian suatu alat ukur dalam melakukan fungsi ukurnya. Pengujian validitas dilakukan dengan program SPSSVersi 16,0Bila nilai signifikansi (sig) hasil korelasi lebih kecil dari 0,05 (5\%) begitupun sebaliknya. Keputusan untuk uji validitas sebagai berikut:

$>$ Jika $\mathrm{r}$ hitung $>\mathrm{r}$ tabel, maka dikatakan Valid

$>$ Jika $r$ hitung $<$ r tabel. Maka dikatakan tidak valid

\section{a. Uji Validitas Penetapan Harga (Variabel X)}

Diketahui nilai $\mathrm{N}=66$ dan nilai koefisien korelasi antar item_1 dengan skor total adalah sebesar 0,456 atau $\mathrm{r}$ hitung $=0.456$ dan nilai sig $=0,000$. $\mathrm{R}$ tabel untuk $\mathrm{N}=66$ dengan signifikansi $5 \%$ pada distribusi nilai $\mathrm{r}$ tabel product moment. Maka ditemukan $r$ tabel sebesar 0,244.

Oleh karena nilai $r$ hitung $0,456>r$ tabel 0,244 dan nilai sig-(2-tailed) $0,000<$ 0,05, maka berdasarkan pengambilan keputusan dalam analisis korelasi dapat di simpulkan bahwa ada korelasi antara item_1 dengan skor total. Dengan demikian dapat diartikan bahwa item soal nomor 1 pada kuesioner tersebut adalah valid sehingga dapat di gunakan sebagai instrumen penelitian. Untuk item soal nomor 2,3,4,5,6,7 juga dapat dikatakan valid dengan melihat tabel sebagai berikut: 
Tabel. 4.5

Hasil Uji Validitas Angket mengenai Penetapan Harga (Variabel X)

\begin{tabular}{|c|c|c|c|c|}
\hline No Item & $\begin{array}{c}\text { R_Hitung } \\
\text { (Person Corelation) }\end{array}$ & R_Tabel & Signifance & Keterangan \\
\hline 1 & .456 & .244 & .000 & Valid \\
\hline 2 & .406 & .244 & .001 & Valid \\
\hline 3 & .618 & .244 & .000 & Valid \\
\hline 4 & .252 & .244 & .041 & Valid \\
\hline 5 & .280 & .244 & .023 & Valid \\
\hline 6 & .749 & .244 & .000 & Valid \\
\hline 7 & .578 & .244 & .000 & Valid \\
\hline
\end{tabular}

Sumber: Data diolah dengan program SPSS 16,0

\section{b. Uji Validitas Minat Jual (Variabel Y)}

Diketahui nilai $\mathrm{N}=66$ dan nilai koefisien korelasi antar item_1 dengan skor total adalah sebesar 0,366 atau $\mathrm{r}$ hitung $=0.366$ dan nilai sig $=0,002$. $\mathrm{R}$ tabel untuk $\mathrm{N}=66$ dengan signifikansi $5 \%$ pada distribusi nilai $\mathrm{r}$ tabel product moment.

Maka ditemukan $r$ tabel sebesar 0,244. Oleh karena nilai $r$ hitung 0,366 $>r$ tabel 0,244 dan nilai sig-(2-tailed) $0,002<0,05$, maka berdasarkan pengambilan keputusan dalam analisis korelasi dapat di simpulkan bahwa ada korelasi antara item_1 dengan skor total. Dengan demikian dapat diartikan bahwa item soal nomor 1 pada kuesioner tersebut adalah valid sehingga dapat di gunakan sebagai instrumen penelitian. Untuk variabel Minat Jual (Y) ada 1 Item yang nilainya kurang dari 0,244 yaitu item soal no 2 sehingga item ini dinyatakan tidak valid jadi harus dibuang atau diperbaiki. Sebagai berikut:

Tabel. 4.6

Hasil Uji Validitas Angket mengenai Harga Jual (Y)

\begin{tabular}{|c|c|c|c|c|}
\hline No Item & $\begin{array}{c}\text { R_Hitung } \\
\text { (Person Corelation) }\end{array}$ & R_Tabel & Signifance & Keterangan \\
\hline 1 & .366 & .244 & .002 & Valid \\
\hline 2 & .186 & .244 & .136 & Tidak Valid \\
\hline
\end{tabular}




\begin{tabular}{|c|c|c|c|c|}
\hline 3 & .484 & .244 & .000 & Valid \\
\hline 4 & .346 & .244 & .004 & Valid \\
\hline 5 & .281 & .244 & .002 & Valid \\
\hline 6 & .484 & .244 & .000 & Valid \\
\hline 7 & .555 & .244 & .000 & Valid \\
\hline 8 & .598 & .244 & .000 & Valid \\
\hline
\end{tabular}

Sumber: Data diolah dengan program SPSS 16,0

\section{Hasil Analisisis Uji Reliabilitas}

Uji Reliabilitas merupakan suatu alat pengukur, dimana dapat dikatakan reliabel bila alat itu dalam mengukur suatu gejala pada waktu yang berlainan senantiasa menunjukkan hasil yang sama. Dalam hal ini metode uji reliabilitas yang sering digunakan adalah Cronbach's Alpha jika nilai Cronbach's Alpha $>0,6$ maka dapat dikatakan reliabilitasas.

\section{a. Uji Reliabilitas Penetapan Harga (Variabel X)}

Dari hasil uji reliabilitas variabel penetapan harga (X) dapat di ketahui nilai Cronbach's Alpha sebesar 0,669. Karna nilai dari variabel penetapan harga (X) diatas 0,6 maka dapat di simpulkan bahwa alat ukur untuk penelitian tersebut di nyatakan reliabel. Seperti yang terdapat dalam tabel berikut :

Tabel. 4.7

Uji Reliabilitas untuk Penetapan Harga (Variabel X)

Reliability Statistics

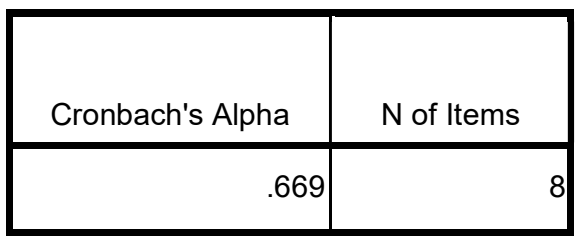

Sumber : Data diolah dengan progam SPSS versi 16,0

\section{b. Uji Reliabilitas Minat Jual (Variabel Y)}

Dari hasil uji reliabilitas variabel Minat Jual (Y) dapat di ketahui nilai Cronbach's Alpha sebesar 0,640. Karna nilai dari variabel Minat Jual (Y) diatas 0,6 maka dapat di simpulkan bahwa alat ukur untuk penelitian tersebut di nyatakan reliabel. Seperti yang terdapat dalam tabel berikut : 
Tabel. 4.8

Uji Reliabilitas untuk Minat Jual (Variabel Y)

Reliability Statistics

\begin{tabular}{|r|r|}
\hline Cronbach's Alpha & N of Items \\
\hline .640 & \\
\hline
\end{tabular}

Sumber : Data diolah dengan progam SPSS versi 16,0

\section{Hasil Analisis Regresi Linier Sederhana ${ }^{6}$}

Dasar pengambila keputusan untuk regresi linier sederhana dapat mengacu pada dua hal sebagai berikut:

a. Membandingkan nilai signifikansi dengan nilai probabilitas $\mathbf{0 , 0 5}$

> Jika nilai signifikansi $<0,05$ variabel $\mathrm{X}$ berpengaruh terhadap variabel $\mathrm{Y}$.

$>$ Jika nilai signifikansi $>0,05$ Variabel X Tidak Berpengaruh terhadap variabel Y

b. Membandingkan nilai $t$ hitung dengan $t$ tabel

Jika nilai $t_{\text {hitung }}>t$ tabel, artinya variabel $X$ berpengaruh terhadap variabel $Y$.

$>$ Jika nilai $\mathrm{t}_{\text {hitung }}<\mathrm{t}$ tabel, artinya variabel $\mathrm{X}$ tidak berpengaruh terhadap variabel Y.

Tabel. 4.9

Hasil uji Regresi Linier Sederhana untuk ANOVA ANOVA $^{\mathrm{b}}$

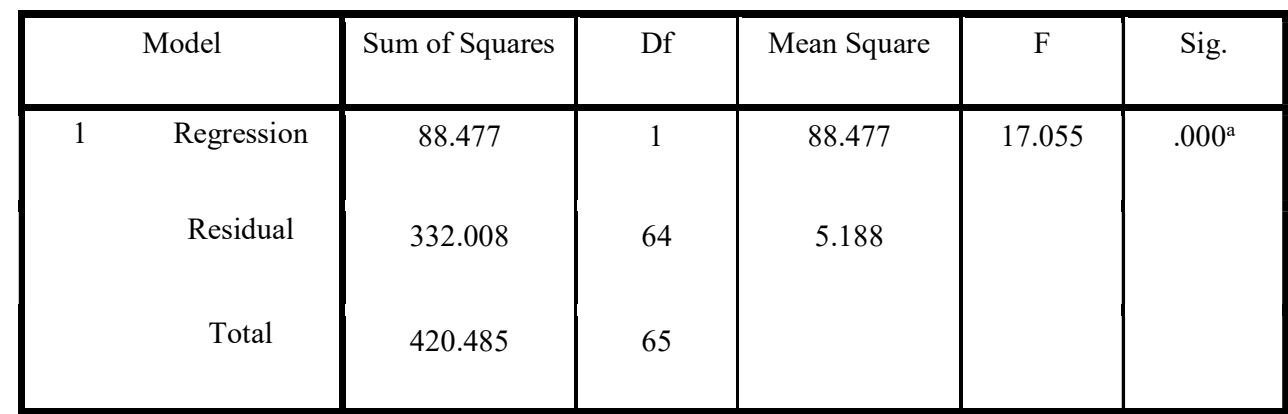

a. Predictors: (Constant), Penetapan Harga

b. Dependent Variable: Minat Jual

Sumber : Data diolah dengan progam SPSS versi 16,0 
Dari tabel diatas dapat di ketahui bahwa nilai $\mathrm{F}$ hitung 17.055 dengan tingkat signifikansi sebesar $0,000<0,05$, maka model regresi dapat di pakai untuk meprediksi variabel penetapan harga $(\mathrm{X})$ berpengaruh terhadap Variabel minat jual (Y).

Tabel. 4.10

Hasil uji Regresi Linier Sederhana untuk Coefficients

Coefficients ${ }^{\mathrm{a}}$

\begin{tabular}{|c|c|c|c|c|c|}
\hline \multirow[b]{2}{*}{ Model } & \multicolumn{2}{|c|}{ Unstandardized Coefficients } & \multirow{2}{*}{$\begin{array}{c}\begin{array}{c}\text { Standardized } \\
\text { Coefficients }\end{array} \\
\text { Beta }\end{array}$} & \multirow[b]{2}{*}{$\mathrm{t}$} & \multirow[b]{2}{*}{ Sig. } \\
\hline & B & Std. Error & & & \\
\hline (Constant) & 19.593 & 2.411 & & 8.125 & .0 \\
\hline Penetapan Hrga & .424 & .103 & .459 & 4.130 & \\
\hline
\end{tabular}

a. Dependent Variable: Minat Jual

\section{Sumber : Data diolah dengan progam SPSS versi 16,0}

Diketahui nilai constanta (a) sebesar 19,593, sedang nilai penetapan harga sebesar 0,424 sehingga persamaan regresinya dapat di tulis:

$$
\begin{aligned}
& Y=\mathbf{a}+\mathbf{b X} \\
& Y=\mathbf{1 9 , 5 9 3}+\mathbf{0 , 4 2 4 X}
\end{aligned}
$$

Persmaan tersebut dapat di terjemah:

$>$ Kostanta sebesar 19,593, mengandung arti bahwa nilai konsisten variabel minat jual adalah sebesar 19,593.

$>$ Koefesiensi variabel penetapan harga (X) sebesar 0,424 menyatakan bahwa setiap penambahan $1 \%$ nilai penetapan harga, maka nilai minat jual bertambah sebesar 0,424. Koefesiensi regresi tersebut bernilai positif, sehingga dapat dikatakan bahwa arah pengaruh variable penetapan harga $(\mathrm{X})$ terhadap Minat Jual (Y) adalah positif.

$>$ Berdasarkan nilai signifikansi dapat di peroleh nilai signifikansi sebesar $0,000<0,05$, sehingga dapat di simpulkan bahwa variabel penetapan harga (X) berpengaruh terhadap variabel $(\mathrm{Y})$.

Berdasarkan nilai t pada tabel diatas diketahui nilai $t_{\text {hitung }}$ sebesar 4,130 $>\mathrm{t}_{\text {tabel }} 1,998$ (dilihat pada distriusi nilai t tabel), sehingga dapat di simpulkan bahwa variabel penetapan harga $\mathrm{X}$ berpengaruh terhadap variabel minat jual $\mathrm{Y}$. 


\section{Pembahasan}

Dari penjelasan hasil penelitian diatas dapat di jelaskan pembahasan mengenai pengaruh penetapan harga oleh tengkulak terhadap minat penjualan hasil pertanian Kopi di Dusun Komalang Desa Ranuagung Kecamatan Tiris Kabupaten Probolinggo.

Hasil penelitian menunjukan bahwa varibel penetapan harga oleh tengkulak (X) berpengaruh positif dan signifikan terhadap Minat Penjualan hasil pertanian kopi (Y) Kondisi tersebut dapat dilihat dari koefisien variabel penetapan harga yang bernilai 0,424 serta signifikansi sebesar 0,000 (kurang dari 0.05). Sebelum menentukan keputusan responden dalam melakukan transaksi jual beli kopi terlebih dahulu mencari informasi mengenai harga yang di tetapkan oleh para tengkulak sebelum memutuskan menjual hasil panennya, artinya dalam hal ini dampak dari harga yang di tentukan oleh tengkulak berpengaruh terhadap minat jual para petani kopi.

Dengan demikian hipotesis awal yang menyatakan bahwa Ha: Penetapan harga oleh tengkulak tidak berpengaruh terhadap minat penjualan hasil pertanian, walaupun harga beli tengkulak berpengaruh terhadap pendapatan ekonomi petani kopi di tolak dan untuk hipotesis awal yang menyatakan H0 : Penetapan harga oleh tengkulak sangat berpengaruh terhadap minat penjualan hasil pertanian, karena harga beli tengkulak akan sangat berpengaruh terhadap pendapatan ekonomi petani kopi di terima.

\section{Penutup}

\section{Kesimpulan}

Berdasarkan hasil penelitian dan pembahasan, peneliti mengambil kesimpulan sebagai berikut:

a. Secara umum dalam penentuan harga kopi oleh tengkulak adalah melihat dari beberapa aspek, untuk yang pertama melihat pada metode harga pasar, metode penetapan harga berdasarkan harga pasar ditentukan oleh mekanisme harga yang berlaku dipasar. Kedua metode biaya plus, menentukan harga jual dengan metode biaya plus didasarkan pada besarnya biaya yang dikeluarkan untuk menghasilkan produk tersebut, ditambah deng an suatu persentase tertentu dari biaya tersebut. Ketiga metode marjin kontribusi, margin kontribusi adalah selisih antara harga jual dengan biaya variabel suatu produk. Keempat metode laba maksimal, dimana dalam laba maksimal akan lansung mempengaruhi volume penjualan produk tersebut. jika harga jual dinaikkan maka volume penjualan akan lansung berkurang. Jika harga jual produk diturunkan, volume penjualan produk lansung bertambah. Terakhir metode tingkat pengembalian atas modal, tingkat pengembalian yang diharapkan oleh para penanam modal perusahaan mengharuskan perusahaan menggunakannya sebagai dasar untuk menetapkan harga jual produk pada kapasitas produksi yang dimiliki perusahaan.

b. Hasil penelitian menunjukan bahwa varibel penetapan harga oleh tengkulak (X) berpengaruh positif dan signifikan terhadap Minat Penjualan hasil pertanian kopi (Y) Kondisi tersebut dapat dilihat dari koefisien variabel penetapan harga yang bernilai 0,424 
serta signifikansi sebesar 0,000 (kurang dari 0.05). Sebelum menentukan keputusan responden dalam melakukan transaksi jual beli kopi terlebih dahulu mencari informasi mengenai harga yang di tetapkan oleh para tengkulak sebelum memutuskan menjual hasil panennya, artinya dalam hal ini dampak dari harga yang di tentukan oleh tengkulak berpengaruh terhadap minat jual para petani kopi.

\section{Saran}

Dari pemaparan diatas mengenai analisis dampak penetapan haraga oleh tengkulak terhadap minat penjualan hasil pertanian kopi di Dusun Komalang Desa Ranuagung Kecamatan Tiris, maka dapat di paparkan saran sebagai berikut:

a. Diharapkan kepada para tengkulak untuk lebih mengedepankan prinsip saling menguntungkan dalam menentuka harga, tidak memanipulasi harga yang ada di pasaran dan membeli hasil pertanian dengan harga yang cukup rendah.

b. Diharapkan kepada para petani agar bisa menjual barang dengan kualitas barang yang bermutu agar tengkulak tidak segan untuk memberikan harga yang cukup tinggi.

c. Diharapkan kepada tengkulak maupun petani dalam berbisnis bisa mengedepankan prinsip keadilan, dimana baik peodusen maupun konsumen tidak ada yang merasa di rugikan baik dalam segi harga maupun kualitas barang yang di jual.

\section{DAFTAR PUSTAKA}

Artaty, Tinjauan hukum islam tentang praktek tengkulak dalam jual beli karet

Rudianto, Anggaran Bisnis, Jakarta: Erlangga, 2009.

Basu Swasta,Dasar-dasar Marketing, Yogyakarta:Liberty, 2000.

Evi Sapitri, Analisis dampak penetapan harga damar oleh tengkulak terhadap kesejahteraan petani dalam perspektif ekonomi islam, UIN Raden Intan,2018.

Kasmi, kewirausahaan ,jakarta: Rajawali Per, 2013.

Marfuah Siddik "Konsep Penetapan Harga Hasil perikanan dalam perspektif ekonomi islam (Studi kasus pelelanganikan paotere dikota makasar)'Universitas Islam Negeri Alauddin Makassar 2016.

Mas'ud Machfoeds, Mahmud machfoeds, Kewirausahaan, BPFE-Yogyakarta 2015.

Nurul Ulya "Analisis Penentuan Harga Gabah Oleh Tengkulak Menurut Pandangan Ekonomi Islam(Studi Kasus Di Desa Wonoketingal Karanganyar

Demak) ’Sekolah Tinggi Agama Islam Negri Kudus 2017.

Sugiyono,Statistika Untuk Penelitian,Bandung:Alfabeta, 2013. , Metode penelitian kuantitatif, kualitatid dan R\&D, Bandung: Alfabeta, 2013.

Sunarto,Metodologi penelitian, Semarang: UNNES, 2012. 